\title{
FISCAL CONVERGENCE BEFORE ENTERING THE EMU
}


E U R P A N C E N TRAL B A N K

\section{WORKING PAPER SERIES}

NO 664 I JULY 2006

FISCAL CONVERGENCE BEFORE ENTERING THE EMU'

by Luca Onorante ${ }^{2}$
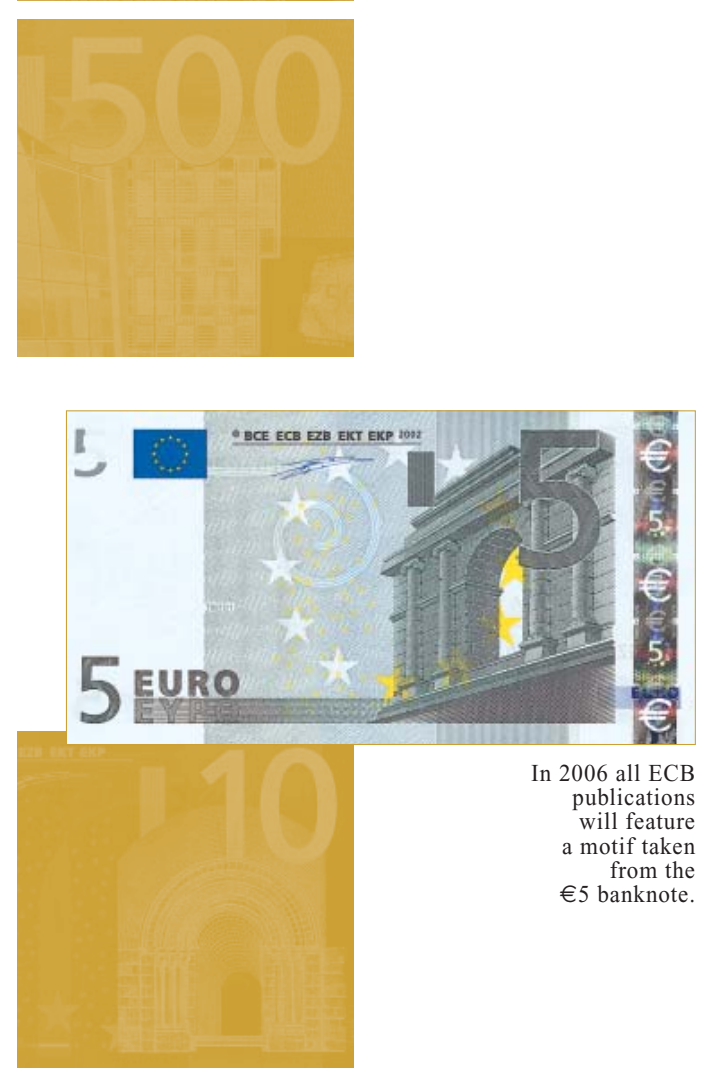

This paper can be downloaded without charge from http://www.ecb.int or from the Social Science Research Network electronic library at http://ssrn.com/abstract_id $=916102$

I I would like to thank Mike Artis for useful comments and discussion. Peter Backé and Ludger Schuknecht also gave me very useful comments. All mistakes are those of the author. The views expressed in this chapter are solely those of the author and do not

necessarily reflect those of the European Central Bank. 
(C) European Central Bank, 2006

\section{Address}

Kaiserstrasse 29

60311 Frankfurt am Main, Germany

\section{Postal address}

Postfach 160319

60066 Frankfurt am Main, Germany

\section{Telephone}

+496913440

\section{Internet}

http://www.ecb.int

\section{Fax}

+496913446000

\section{Telex}

$411144 \mathrm{ecb} d$

All rights reserved.

Any reproduction, publication and reprint in the form of a different publication, whether printed or produced electronically, in whole or in part, is permitted only with the explicit written authorisation of the ECB or the author(s).

The views expressed in this paper do not necessarily reflect those of the European Central Bank.

The statement of purpose for the ECB Working Paper Series is available from the ECB website, http://www.ecb.int.

ISSN 1561-0810 (print)

ISSN 1725-2806 (online) 


\section{CONTENTS}

Abstract

Non-technical summary

1 Introduction

2 The model

2.1 Description of the model

3 Solution of the model

3.1 The role of expectations I5

3.2 Results with backward induction 17

4 Results and policy implications 18

4.1 Entering monetary union I8

4.2 Size of the country and structural differences

4.3 The effect of fiscal constraints

5 Conclusions

Appendix

Notes

References

European Central Bank Working Paper Series 


\begin{abstract}
The monetary integration of the acceding countries will proceed in several distinct steps, starting with membership in the European Union (EU), followed by participation in the so-called Exchange Rate Mechanism (ERM) II and ultimately entry into the euro area. This paper addresses the question of whether a reduction of public deficits, such as imposed by the Maastricht fiscal criteria, is a necessary or useful step on the road to the adoption of the euro.

The question is addressed by examining the interaction of monetary, fiscal and wage policies and their effects on prices in a monetary union hit by economic shocks. The theoretical model shows that fiscal activism is related with both entry in monetary union and with structural differences in the national labour markets, and analyses in detail the effect of both factors. As for acceding countries, the conclusion is that the process of deficit reduction should be completed before entry, as suggested by the Maastricht criteria. The chapter also suggests that fiscal constraints on government deficits appear essential in a monetary union when the wage formation is taken into due consideration.
\end{abstract}

Keywords: Fiscal policy, monetary policy, European Monetary Union, fiscal rules.

JEL Classification Numbers: E61, E62, H30 


\section{Non-technical summary}

In this paper I ask the question of whether a country aiming at adopting the euro should reduce public deficits before entry, as imposed by the Maastricht fiscal criteria. I argue that the conditions of deficit below 3\% already before entry is an useful one, because countries which enter the EMU but did not converge to low levels o deficits will have more difficulties to achieve this convergence afterwards.

The point is illustrated by examining the interaction of monetary, fiscal and wage policies and their effects on prices in a monetary union hit by economic shocks. The model shows that entry in a monetary union leads to increased fiscal activism: a country with high deficits at the moment of entry in the EMU is unlikely to have a sufficient incentive to reduce them later.

In this framework, fiscal criteria have two distinct functions. Before entry, they can be seen as a signal that the fiscal authority of the acceding country has internalized the correct degree of fiscal discipline necessary to stay in the EMU. After entry, constraints on the national fiscal budgets counteract the increased propensity to the use of fiscal policy and limit the externalities on the common monetary policy.

The model of the paper is developed as a game in order to take into account the structural break of EMU and to provide an analytical framework for assessing the potential causes for asymmetry in a monetary union. However, this choice has two main limitations: first, the close form solution is obtained in a simplified framework; second, the phenomenon is examined in isolation, thereby providing insights about how it works but also abstracting from other mechanisms that may work in opposite directions. 


\section{Introduction}

The monetary integration of the acceding countries will proceed in several distinct steps, starting with membership in the European Union (EU), followed by participation in the so-called Exchange Rate Mechanism (ERM) II and ultimately entry into the euro area.

Already the first step, accession, implies full acceptance of the actual and potential rights and obligations that constitute the third stage of EMU, as well as its institutional framework. The new member states will have to consider their economic policies as a matter of common concern, avoid excessive government deficits and adhere to the relevant provisions of the Stability and Growth Pact. The new member states will have to be committed to the medium-term budgetary objective of close-to-balance or in surplus positions and to meeting the objectives of their convergence programmes. Their budgetary policy and outcomes will become subject to the Excessive Deficit Procedure and to the non-sanctioning parts of the Stability and Growth Pact. As far as fiscal policies are concerned, and at the time of writing, these commitments imply that further progress needs to be made in a number of countries before they can apply to enter the euro area.

This paper addresses precisely the question of whether a reduction of public deficits, such as imposed by the Maastricht fiscal criteria, is a necessary or useful step on the road to the adoption of the euro.

Some authors favour a rapid enlargement process of the euro area and argue that the Maastricht convergence criteria are not necessary and should be 
loosened to facilitate this objective. The assumption underlying this position is that fiscal consolidation is equally painful before and after entry in monetary union, and the decision on whether to consolidate before or wait until the entry can then be left to each country. Others believe that after entry it will be more difficult to keep public finances under control. Such an eventuality would be particularly dangerous inside a monetary union, where the inflation caused by loose public finances implies an appreciation of the real exchange rate, and a loss of competitiveness. This second group argues against the adoption of the euro by countries that have not previously reached a high level of sustainable fiscal convergence.

The paper examines the interaction of monetary, fiscal and wage policies and their effects on prices in a monetary union hit by economic shocks under the hypothesis that fiscal policy has an effect on aggregate demand. It examines what is considered to be the most interesting case, when governments have some deficit bias. The theoretical model shows that the use of discretionary countercyclical fiscal policy is increased by both entry in monetary union and structural differences in the national labour markets, and analyses in detail the effect of both factors. As for acceding countries, the conclusion is that the process of deficit reduction should be completed before entry, as suggested by the Maastricht criteria. The study also suggests that fiscal constraints on government deficits appear essential in a monetary union when wage formation is taken into due consideration. Finally, it is shown that different structures of national labour markets make monetary policy more difficult in a monetary union than in the one-country case. 
More specifically, this paper argues that:

- First and most important, entry in a monetary union leads to increased fiscal activism . This conclusion does not depend on any switch in preferences, and should be considered as an inevitable fact for any country joining a monetary union.

- The capacity of the central bank to keep inflation close to targets without continuous interventions is much smaller in a monetary union than in the one country case. The most conservative central bank can reduce, but not eliminate, this problem. Therefore, a process of previous reduction of public deficits and inflationary pressures by new members also facilitates a monetary policy oriented to price stability.

- The effects of the common monetary policy are influenced by the structure of the national wage-setting process. As in Calmfors and Driffil (1988), decentralized wage bargaining produces higher wage inflation and unemployment in a country. Mechanisms to eliminate the externalities in the wage setting process could be beneficial.

- In a monetary union, constraints on the national fiscal budgets are effective in re-establishing monetary dominance. They also ensure an ex-post policy mix of stability-oriented monetary policy, sustainable fiscal policies and moderate wage inflation.

- From the methodological point of view, the paper takes into account the structural break of EMU and provides an analytical and conceptual framework for assessing the potential causes for asymmetry in a monetary union. 
The structure of the paper is as follows. Section 2 presents and describes in detail the model. The solution of the game between fiscal, monetary and wagesetting authorities is provided in Section 3, both with explicit expectations and with backward induction. Section 4 presents the main results and deals with the policy implications of the model. Finally, Section 5 summarizes the findings.

\section{The model}

\subsection{Description of the model}

The illustrative model is a simple linear-quadratic, one-shot game. My choice of a game theory model is motivated by the relevance of the Lucas critique in the context of the paper. One important implication of the Lucas critique is that any structural change in a part of an economic system also changes the behaviour of all other agents. In the case of a monetary union, the transfer of monetary policy to a supra-national level implies that one cannot expect the unions and the government to behave in the same way as before, even if their preferences remain exactly the same. I consider a Barro-Gordon type of model and concentrate on a country belonging to a monetary union. The basic hypotheses of the model are described here.

I assume some structural parameters of labour markets as given, because there are no signs of a very rapid change of the national labour market as 
a consequence of EMU, and even less of the creation of an EU-wide labour market.

The model focuses on stabilization of the cycle, not on systematic biases. Therefore, I assume that the long-run targets are agreed among the different players and that tastes differ on stabilization only. Even under this optimistic scenario the dynamics are quite rich, and several problems arise.

The central bank of a monetary union reacts to union-wide economic indicators, and its actions may propagate shocks to one country to the others. Similarly, fiscal policy has spillovers on neighbouring countries. I am neglecting both monetary and fiscal externalities in order to allow a simple treatment of the strategic interaction of the players. For a paper taking into account the 'Domino effect' of fiscal policies caused by monetary externalities, see Onorante (2004).

In the model, both workers' unions and fiscal authorities have a larger preference for output stabilization than the central bank. I believe this hypothesis is justified in Europe by the statute of the ECB. To ensure a simpler model I assume that the governments have totally delegated the objective of inflation stabilization to the central bank. This parametrization is not restrictive, as its relaxation does not alter the qualitative results of the model.

Finally, and purely for explanatory purposes, the paper uses a reduced-form description of the economies and explores the case which is most perceived to be problematic: an asymmetric shock to output that cannot be dealt with by the common monetary policy. 
The common monetary policy is decided by a federal central bank. The central bank is interested in union-wide inflation $\tilde{p}$ and (possibly) output $\tilde{y}$, both expressed as deviations from targets, and seeks to minimize the following loss function:

$$
\min _{\tilde{r}} L_{C B}=\left(\tilde{p}^{2}+\beta \tilde{y}^{2}\right)
$$

The parameter $\beta$ expresses the relative aversion of the central bank to inflation and unemployment.

The central bank chooses a union-wide policy variable $\tilde{r}$, such as a nominal interest rate, after observing the deviations from targets of inflation and output of the whole union. Variables with a tilde denote union-wide aggregates. A union-wide variable is defined as the weighted sum of the corresponding national variables with the weights $\phi$ denoting the size of each country in the monetary union: $\tilde{x}=\Sigma_{i} \phi_{i} x_{i},\left\{\phi_{i}: \Sigma_{i} \phi_{i}=1\right\}$

The national fiscal policy is decided by the government, seeking to minimize a loss function including national (without tilde) output $y$ and deficit $g$, bothe expressed in deviations from targets ${ }^{1}$ :

$$
\min _{g} L_{G}=\left(y^{2}+\gamma g^{2}\right)
$$

conditional to the observed shocks and wage policies, and backward inducting on the central bank. The parameter $\gamma$ expresses the relative preference for deficit stabilization. The target variable $p$ is not included because the goal of 
price stability has been assigned to the central bank for the whole union. I will explicitly model only one country, with weight $\phi$ in the monetary union.

The national wages are determined as the outcome of a decentralized bargaining process. For tractability, I suppose that in the country there are $1 / \psi$ identical unions, each of them representing a fraction $\psi$ of workers. Each union $j=1,2, . .1 / \psi$ minimizes a loss function of the form

$$
\min _{w_{j}} L_{U j}=\left(y^{2}+\omega\left(w_{j}-p\right)^{2}\right)
$$

including deviations from target unemployment $y$ and real wage inflation $\left(w_{j}-p\right)$ of the workers it represents. The collective outcome (symmetric Nash equilibrium) of the decentralized wage negotiation is the level of wages $w$ in the country:

$$
\begin{aligned}
w & =\Sigma_{j} \psi_{j} w_{j} \\
& =w_{j} \forall j
\end{aligned}
$$

The national macro variables (inflation and output) are linearly related to the output shock $(\eta)$, the growth rate of wages $(w)$ and the policy instruments $(g, \tilde{r})$. Expectations are set in advance, therefore the aggregate supply curve is upward sloping. As a consequence, monetary, fiscal, and wage policies affect output and inflation by moving aggregate demand. The reduced form equations are: 


$$
\begin{aligned}
& y=g-\tilde{r}-\lambda w-\eta \\
& p=g-\tilde{r}+\lambda w
\end{aligned}
$$

where $\tilde{r}$ is the union-wide interest rate chosen by the central bank, $g$ is the fiscal policy stance of the national government, $w$ is the national wage level, $\eta$ an observable shock to output ${ }^{2}$ and $\lambda<1$ is a structural parameter describing the effect of wage inflation on price inflation. The Appendix shows that the equations are compatible with a standard AS-AD model.

The assumption that fiscal and monetary policy are perfect substitutes follows Nordhaus (1994). The assumption is obviously a simplification and ignores relevant second-order effects such as the different effect that fiscal and monetary policy have on interest rates, exchange rates, and sectoral prices. However, I have shown in Onorante (2003) that a more general setup would not change the qualitative conclusions.

The order of the moves has been chosen in a way that most reflects the actual setup of EMU. In a game between unions, fiscal and monetary authorities, the participants come to some understanding of the strategy of the others. As a consequence, at each step of the game the players will take as given the preceding decisions and form expectations (backward induct) on the following ones. I will then discard the simplest case, the Nash equilibrium, in which each authority takes as given the decisions of the others, because I consider it little more than a theoretical case. 
Instead, I chose the following order of the moves: the shock $\eta$ comes obviously first, the workers' unions determine (each of them playing Nash to the others) the national wage level $w$, then the national fiscal policy $g$ is decided, finally the central bank observes the union-wide aggregates and chooses $\tilde{r}$ accordingly.

The choice of letting the central bank move last is quite common in the literature, and easy to justify. ${ }^{3}$ First, in most monetary unions monetary policy makers have a coherent and understandable strategy that explicitly depends on macro variables, while fiscal policy tends to be more erratic and depend on elections, personalities and coalitions, but hardly on moral suasion by the central bank. Also, monetary policy is fast in reacting to external changes in the economy, including changes in the fiscal stance of member states, while fiscal policy is the result of a long process of negotiation by policy makers and hardly qualifies as a variable that the central bank can directly influence in the short run.

The choice of letting the unions play before the fiscal authority comes from similar considerations: first, there may be (and normally there are) many unions in a country, and their reactions are therefore more difficult to anticipate than those of the fiscal policy. Second, wages are normally determined for many years and the contracting process is much more dispersed and slower than the one leading to fiscal policy. 


\section{Solution of the model}

\subsection{The role of expectations}

The central bank reacts to the effect on union-wide variables. In case of an asymmetric shock in a country with weight $\phi \in(0,1]$ the aggregate variables react as:

$$
\begin{aligned}
& \tilde{y}=\phi(g-\lambda w-\eta)-\tilde{r} \\
& \tilde{p}=\phi(g+\lambda w)-\tilde{r}
\end{aligned}
$$

Solving the central bank's minimization problem gives the following expression for $r$ :

$$
\tilde{r}=\phi\left(g+\alpha_{1} \lambda w-\alpha_{2} \eta\right)
$$

with $\alpha_{1}=\frac{(1-\beta)}{1+\beta}, \alpha_{2}=\frac{\beta}{1+\beta}$. The interest rate is decreased in the event of a negative output shock unless the central bank is a pure inflation targeter $(\beta=0)$ and it is always increased in response of a fiscal expansion. The response to an increase in the wage level is theoretically ambiguous, but positive for normal values of the parameters $(\beta<1)$, that is unless the central bank cares more about output than about prices. Finally, the reaction of the central bank is proportional to the size of the country in the monetary union. 
The national government targets the national aggregates

$$
\begin{aligned}
& y=g-\tilde{r}^{e}-\lambda w-\eta \\
& p=g-\tilde{r}^{e}+\lambda w
\end{aligned}
$$

and the resulting fiscal policy is

$$
g=\frac{1}{1+\gamma}\left(\tilde{r}^{e}+\lambda w+\eta\right)
$$

The fiscal authority faces a cost in changing the fiscal stance. Hence, the multiplicator outside the parentheses is less than one, and decreasing in $\gamma$, the parameter that indicates the cost of discretionary fiscal policy moves. The fiscal policy stance is eased if a negative shock hits the economy, in order to compensate for the additional unemployment coming from an excessive wage inflation, or to smooth the domestic real effects of an expected monetary tightening.

Finally, wages are set by unions playing Nash with each other. The Nash equilibrium describes the solution under no cooperation: each union in the country plays as if the other unions had decided their wages already. As a consequence, the effects of a wage increase on macroeconomic variables perceived by the average union are given by $\lambda \psi$ : the smaller the size $\psi$ of the union, the less the effect of a wage increase on prices and unemployment will be taken into consideration.

$$
\begin{aligned}
& y=\left(g^{e}-\tilde{r}^{e}\right)-\lambda \psi w-\eta \\
& p=\left(g^{e}-\tilde{r}^{e}\right)+\lambda \psi w
\end{aligned}
$$


the resulting wage inflation is

$$
w=\frac{(\omega-\omega \lambda \psi+\lambda \psi)\left(g^{e}-\tilde{r}^{e}\right)-\lambda \psi \eta}{(\lambda \psi-1)^{2} \omega+(\lambda \psi)^{2}}
$$

\subsection{Results with backward induction}

This section shows the solution of the model when expectations are formed by backward induction. The central bank moves last, after observing the moves of all the other players:

$$
\tilde{r}=\phi\left(\tilde{g}+\alpha_{1} \lambda \tilde{w}-\alpha_{2} \tilde{\eta}\right)
$$

For all possible values of $\phi$ (excluding 1) the federal central bank lowers interest rates in response to a negative shock and increases them in response to wage inflation and public deficit. The size of the intervention is proportional to $\phi$.

The government observes $\eta$ and $w$ and backward inducts on the ECB. Substituting (12) into the expectations of (9) one obtains the expression for fiscal policy:

$$
g=(1-\phi) \frac{\left(1+\phi \alpha_{1}\right) \lambda w+\left(1-\phi \alpha_{2}\right) \eta}{(1-\phi)^{2}+\gamma}
$$

For all possible values of $\phi$ (excluding 1) the backward-inducting government eases the fiscal stance in response to both a negative shock and an increase in nominal wages. In the one country case $(\phi=1)$ the central bank was able 
to discipline the fiscal authority and to influence the expectations of the wage setters; in a monetary union part of this power is lost.

The unions backward induct on both the central bank and the government, therefore (12) and (13) are substituted into (11) in order to obtain the expression for the wages:

$$
w=\frac{\left(1-2 \phi+\phi \alpha_{2} \gamma+\phi^{2}\right) \omega B+\left(-\phi \alpha_{2} \gamma+\gamma\right) A}{\left((1-\phi)^{2}+\gamma+\lambda \psi\left(\gamma\left(\phi \alpha_{1}-1\right)-2(\phi-1)^{2}\right)\right) \omega B-\lambda \psi \gamma\left(1+\phi \alpha_{1}\right) A} \eta
$$

with

$$
\begin{aligned}
& A=\frac{d y}{d w}=-\lambda \psi \gamma \frac{\left(\phi \alpha_{1}+1\right)}{(1-\phi)^{2}+\gamma} \\
& B=\frac{d(w-p)}{d w}=1+\lambda \psi \frac{\gamma\left(\phi \alpha_{1}-1\right)-2(\phi-1)^{2}}{(1-\phi)^{2}+\gamma}
\end{aligned}
$$

Equations (12, 13 and 14) constitute the complete solution of the model with backward induction. In order to provide better insights into the economic implications of this model, the next section highlights some specific issues.

\section{Results and policy implications}

\subsection{Entering monetary union}

Before entering monetary union, the country can be thought of as belonging to a monetary union with itself only. The outcomes are thus described by (14) and (13) under the assumption that $\phi=1$. 


$$
\begin{aligned}
w & =\frac{\left(1+\lambda \psi\left(\alpha_{1}-1\right)\right) \alpha_{2} \omega+\left(\alpha_{2}-1\right) \lambda \psi\left(1+\alpha_{1}\right)}{\left(1+\lambda \psi\left(\alpha_{1}-1\right)\right)^{2} \omega+(\lambda \psi)^{2}\left(1+\alpha_{1}\right)^{2}} \eta \\
g & =0 \\
\tilde{p} & =\left(1-\alpha_{1}\right) \lambda w+\alpha_{2} \eta
\end{aligned}
$$

Comparing the previous equations with (13), one can immediately see that the structure of policy interaction differs fundamentally. Before entering the monetary union, the national central bank is always able to 'discipline' fiscal policy according to its own preferences (in this case, $g=0)^{4}$. An even stronger result holds: if the national central bank is a pure inflation targeter, both government and wage setters have to adapt their policies in such a way that the inflation target is attained. This result follows from equations (15), where $\beta=0$ (pure inflation targeting) implies $\alpha_{1}=1, \alpha_{2}=0$. Substituting into the third equation, one obtains $\tilde{p}=0$. Neither result holds after entrance in the monetary union, and both fiscal and monetary targets are missed after a shock.

One can conclude that, despite the agreement of the long-run targets between the different authorities, the statement of Dixit and Lambertini (2001, 2003) that 'fiscal discretion destroys monetary commitment' is confirmed even in the short-run perspective of this paper. The incentives to the active use of fiscal policy increase in a monetary union, where every individual country is tempted to take advantage of the common monetary policy by running deficits with much of the costs in terms of higher interest rates affecting the other member countries $^{5}$. The new element is that the wage setters internalize the new fiscal 
behaviour in their expectations and tend to exploit the new framework in a similar way, further increasing the incentives to the use of discretional fiscal policy.

\subsection{Size of the country and structural differences}

The complexity and non-linearity of the expressions for the variance of fiscal policy and prices make the close-form solution $(12,13,14)$ cumbersome. Thus, I prefer a graphical representation. Figure 1 illustrates the size of the average fiscal expansion after a negative output shock for all values of $\phi$ and $\psi$. The other parameters have been chosen in order to illustrate the results, different values have been tried and they do not change the qualitative conclusions. The colour of the surface depends on the value of the data point, and two lighter bands have been imposed at $\phi=1$ and $\phi=0.1$ to highlight respectively the one-country case and the average-sized member of a monetary union. 


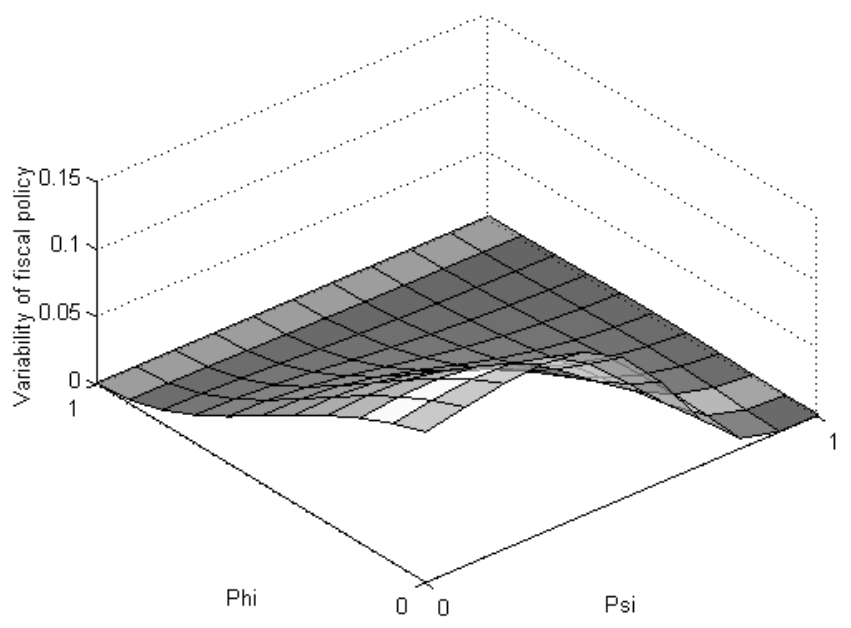

Figure 1: Variance of fiscal interventions after a shock

The results for the one-country case (equation 15) are confirmed by the simulation: for every level of centralization of wage bargaining, the central bank is able to fully control the fiscal policy, and the variability is then zero. When the country enters the monetary union (lighter band at $\phi=0.1$ ) this effect of discipline is maintained only if wage bargaining is centralized $(\psi=1)$ so that wage setters internalize the effect on prices of higher wages. The more wages are determined by decentralized bargaining, the more fiscal policy offsets the unemployment that arises as externality. 


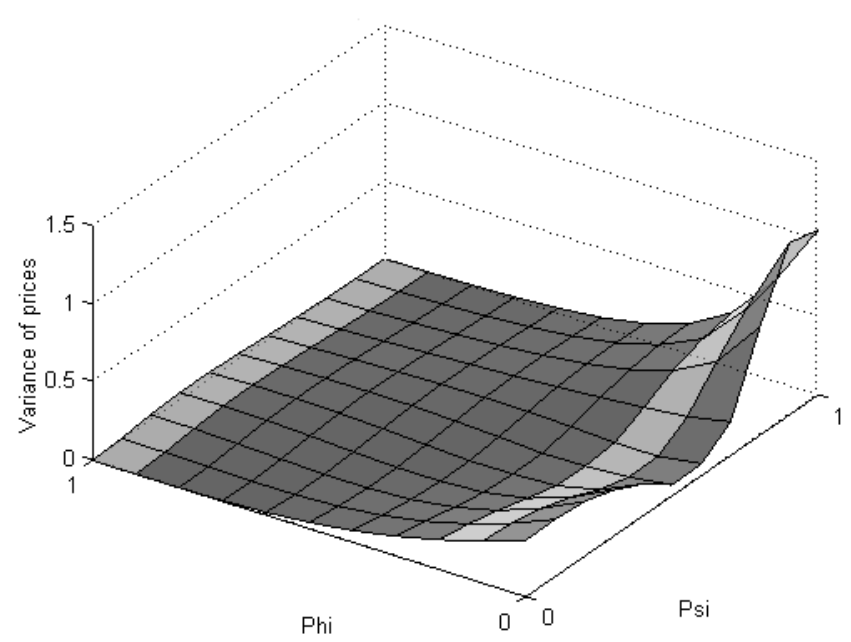

Figure 2: Variance of prices after a shock

The results on price variability are consistent with the previous findings. In the one-country case, the variance of prices is extremely limited (Figure 2; see again the $\phi=1$ lighter stripe). In a monetary union, prices are driven by two different forces: on the one hand, fiscal policy takes advantage of the reduced capacity of the central bank to respond, and this increases prices. On the other hand, a centralized wage setting is able to limit the inflation of wages (and thus prices) accordingly, while this is not true of decentralized bargaining. The interaction of these two forces produces the $\mathrm{u}$-shaped stripe at $\phi=0.1$. The variance is minimal when the two forces offset each other, maximal if wages are reduced (one union, $\psi=1$ ) or if fiscal policy is expanded in order to preserve employment after a high wage increase $(\psi=0)$.

A general conclusion could be that the federal central bank of a monetary union has more problems in controlling inflation than a national central bank. The possibility of free riding by the national governments and the incapacity of 
the federal central bank to target individual national imbalances makes interventions less efficient and increases the variability of inflation.

\subsection{The effect of fiscal constraints}

In Europe, the consideration that a monetary union may multiply the effects of any deficit bias led to the establishment of the fiscal criteria in the Stability and Growth Pact. The budgetary rules aim at tying the governments' hands and insulating central banks from possible pressures arising from undisciplined members of the union. The Pact states that the ratio of the annual government deficit to gross domestic product (GDP) must not exceed $3 \%$. When the threshold is reached, expanding fiscal policy will not be possible. Without loss of generality, and in order to simplify notation, we set the threshold to zero $(g=0)$ in our model.

Are fiscal constraints really necessary in a monetary union? The answer provided by Figure 3 shows the final effect on inflation of a shock when fiscal policy is free to act. the relevant case is when $\phi$ is small, that is whe the country is part of a monetary union. It can be seen that in case of a centralized labour market $(\psi=1)$ the shock has a limited impact on prices. However, when $\psi$ is smaller the interaction of policies leads to an increase in the final prices that further deteriorates the competitive position of the country affected. At least in these cases fiscal constraints would be beneficial. 


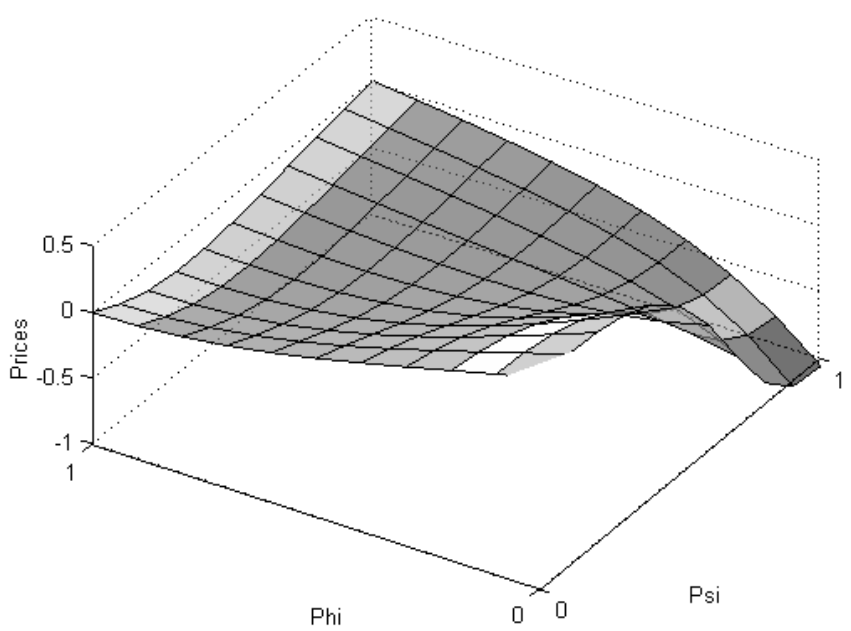

Figure 3: Effect on prices of a unitary shock

Figure 2 confirms that the inflation is more difficult to control in a monetary union than in the one-country case. The answer seems therefore decidedly positive.

Are fiscal criteria really helpful? Consider how fiscal policy affects the dynamics of wages (with backward induction on the central bank) and ex-post monetary policy: from (11) and (7) and imposing $g=0$ one obtains for every $\psi, \phi<1$ that

$$
\begin{aligned}
\frac{d r}{d g} & =\phi>0 \\
\frac{d w}{d g^{e}} & =\frac{(\phi-1)(-\omega+\omega \lambda \psi-\lambda \psi)}{(\omega-\omega \lambda \psi+\lambda \psi) \phi \alpha_{1} \lambda+\lambda^{2} \psi^{2}+(\lambda \psi-1)^{2} \omega}>0
\end{aligned}
$$

Equations (16) show the fundamental role played by the constraints to fiscal policy in allowing the central bank to control inflation. Removing the fiscal bias influences the ex post monetary policy and disciplines the ex ante wage 
dynamics; the effect is even larger if one considers that an unconstrained fiscal policy would respond positively to wage inflation. One should notice that even though the model has been built on symmetric loss functions for all the players, the fiscal constraints become binding only on the inflationary side, and they never impede budget consolidation when necessary. The result of the fiscal constraints is implicit coordination characterized by lower deficits, low interest rates and controlled inflation. Once again there is not an explicit welfare analysis in this paper, but there is a strong consensus in the literature (for example Nordhaus, 1994) that an equilibrium of sustainable fiscal policies and loose monetary policy is better than a combination of loose fiscal and tight monetary policy.

\section{Conclusions}

The paper develops a model of policy interactions in a monetary union, focusing on wage dynamics, fiscal and monetary activism and their consequences on inflation. The simple ${ }^{6}$ model is capable of grasping and making explicit the strategic interactions of the different policy makers, and shows that lower deficits should be attained before entrance in a monetary union. The following conclusions emerge:

- First and most important, fiscal activism is always increased by entry in monetary union. This conclusion does not depend on any switch in preferences, and should be considered as an inevitable fact for any country joining a monetary union. 
- The capacity of a central bank to keep inflation close to targets is much smaller in a monetary union than in the one-country case. Furthermore, the model shows that the single monetary policy can lead to very different price dynamics in different countries of the union. A conservative central bank can reduce but not eliminate this problem.

- The former two points imply that a strategy of convergence in public finances prior to entry in a monetary union may be preferable both for the acceding country and the stability of the existing monetary union. Entry in a monetary union should be a decision that the candidate countries take on the basis of economic fundamentals. For Europe, the Maastricht deficit criterion provides the appropriate incentives to achieve low levels of public deficit before entry in the EMU.

- The effects of the common monetary policy are also influenced by the structure of the national wage-setting process. The model shows that mechanisms to eliminate the externalities in the wage setting process could be beneficial.

- Fiscal constraints should remain after entry in the monetary union, as they are effective in re-establishing monetary dominance. They also ensure an ex-post policy mix of stability-oriented monetary policy, sustainable fiscal policies and moderate wage inflation. 
- From the methodological point of view, the paper takes into account the structural break of entry in EMU and provides an analytical and conceptual framework for assessing the potential causes for asymmetry in the monetary union.

The goal of this paper was not to take into account all possible factors, but to disentangle a relevant mechanism of interaction among players which is typical of a monetary union. The conclusions cannot be considered as absolute statements, as they may not be valid in the context of a different modelization. There are, furthermore, several ways in which the paper could be developed. First, the analytical framework is extremely simplified and could be enriched by adding systematic biases for the national governments and the unions, in order to obtain results that are valid for the steady state and not only for cyclical fluctuations. Alternatively, the asymmetry in the preferences of the governments in responding to a positive or a negative shock could be explicitly modeled. Other relevant phenomena, such as international spillovers, the exchange rate of the common currency, differences in tastes between the countries, may affect the results in various ways. These are interesting topics for future research.

\section{Appendix}

Here I show the derivation of from a simple AD-AS framework with some prices set in advance and rational expectations formed before the shocks are observed.

Demand and supply can be represented as: 


$$
\begin{aligned}
& y^{d}=-p+\phi(g-r)+e^{d} \\
& y^{s}=\left(p-p^{e}\right)-\lambda w-e^{s}
\end{aligned}
$$

where all the variables are expressed in difference from targets $(m, g, w)$ or long-run levels $(y, p)$. The demand and supply shocks are $e^{d}$ and $e^{s}, \lambda$ is a fixed parameter, which shows that wage inflation is reflected on inflation (with a parameter $\lambda<1$ ), since wages are only one of the production factors in the economy.

The reduced form is obtained by solving for the equilibrium $\left(y^{d}=y^{s}\right)$, fixing the expectations $\left(p^{e}=0\right)$ and rescaling the equations:

$$
\begin{aligned}
& y=\phi(g-r)-\lambda w+\left(e_{d}-e_{s}\right) \\
& p=\phi(g-r)+\lambda w+\left(e_{d}+e_{s}\right)
\end{aligned}
$$

After renaming the parameters, one obtains the final equations (5). For expositional purposes, the shock in the second equation is dropped in the paper.

\section{Notes}

${ }^{1}$ The inclusion of $g$ both as a target variable and instrument is a slight abuse of notation. A variable which is a goal and an instrument can be better represented as two variables in a 1 to 1 relationship, in which the instrument 
perfectly controls the target variable. The use of a single letter is to keep the notation simple. The economic intuition for the inclusion of deficit as a goal is analogous to the popular argument of interest rate smoothing for central banks: changing drastically the deficit level has a cost. The target deficit can be justified on many grounds. For example, it can be though of as a deficit level which ensures sustainability, as excessive deficits lead to accumulation of debt and possibly to insolvency.

${ }^{2}$ The case under analysis is a shock to output. For expositional purposes, the price shock in the second equation is dropped in the chapter (but present in the appendix).

${ }^{3}$ This is often referred to in the literature as fiscal dominance. Monetary dominance of a single central bank over many fiscal authorities in a monetary union is even less realistic than the Nash Equilibrium. In EMU, monetary dominance is ensured by the SGP.

${ }^{4}$ The extreme one country stabilization result comes from the fact that the central bank reacts in such a way to completely offset the fiscal move, thus imposing the amount of stabilization given by its own preferences.

${ }^{5}$ This is a descriptive conclusion, and does not imply a negative judgement. One could also argue that there is an additional need to stabilize the economy through fiscal policy if monetary policy is unavailable as a national policy instrument.

${ }^{6}$ The model is simple because the agents agree on the long-run targets and their preferences differ on the degree of stabilization only. 


\section{References}

[1] Calmfors L. and Driffill J. (1988) 'Centralization of Wage Bargaining', Economic Policy 6: 12-61

[2] Dixit, A. and L. Lambertini (2003), 'Symbiosis of Monetary and Fiscal Policies in a Monetary Union', Journal-of-International-Economics. August 2003; 60(2): 235-47.

[3] Dixit, A. and L. Lambertini (2001), 'Monetary-Fiscal Policy Interactions and Commitment versus Discretion in a Monetary Union', EuropeanEconomic-Review. May 2001; 45(4-6): 977-87.

[4] Nordhaus (1994), 'Policy games: coordination and independence in monetary and fiscal policies', Brookings Papers on Economic Activity, 2, 1994.

[5] Onorante, L. (2003), 'Fiscal, monetary and wage policies in a MU: is there a need for fiscal rules?', mimeo.

[6] Onorante, L. (2004), 'Interaction of fiscal policies on the euro area: how much pressure on the ECB?', in Monetary Policy, Fiscal Policies and Labour Markets: Macroeconomic Policy Making in the EMU, edited by R. Beetsma, C. Favero, A. Missale, A. Muscatelli, P. Natale, P. Tirelli, Cambridge University Press, 2004; 157-190. 


\section{European Central Bank Working Paper Series}

For a complete list of Working Papers published by the ECB, please visit the ECB's website (http://www.ecb.int)

600 "A speed limit monetary policy rule for the euro area” by L. Stracca, April 2006.

601 "Excess burden and the cost of inefficiency in public services provision" by A. Afonso and V. Gaspar, April 2006.

602 "Job flow dynamics and firing restrictions: evidence from Europe" by J. Messina and G. Vallanti, April 2006.

603 “Estimating multi-country VAR models" by F. Canova and M. Ciccarelli, April 2006.

604 "A dynamic model of settlement" by T. Koeppl, C. Monnet and T. Temzelides, April 2006.

605 “(Un)Predictability and macroeconomic stability” by A. D’Agostino, D. Giannone and P. Surico, April 2006.

606 "Measuring the importance of the uniform nonsynchronization hypothesis" by D. A. Dias, C. Robalo Marques and J. M. C. Santos Silva, April 2006.

607 "Price setting behaviour in the Netherlands: results of a survey" by M. Hoeberichts and A. Stokman, April 2006.

608 "How does information affect the comovement between interest rates and exchange rates?" by M. Sánchez, April 2006.

609 "The elusive welfare economics of price stability as a monetary policy objective: why New Keynesian central bankers should validate core inflation” by W. H. Buiter, April 2006.

610 “Real-time model uncertainty in the United States: the Fed from 1996-2003" by R. J. Tetlow and B. Ironside, April 2006.

6 II "Monetary policy, determinacy, and learnability in the open economy" by J. Bullard and E. Schaling, April 2006.

612 "Optimal fiscal and monetary policy in a medium-scale macroeconomic model" by S. Schmitt-Grohé and M. Uribe, April 2006.

613 "Welfare-based monetary policy rules in an estimated DSGE model of the US economy" by M. Juillard, P. Karam, D. Laxton and P. Pesenti, April 2006.

614 "Expenditure switching vs. real exchange rate stabilization: competing objectives for exchange rate policy" by M. B. Devereux and C. Engel, April 2006.

$6 I 5$ “Quantitative goals for monetary policy” by A. Fatás, I. Mihov and A. K. Rose, April 2006. 
616 "Global financial transmission of monetary policy shocks" by M. Ehrmann and M. Fratzscher, April 2006.

617 “New survey evidence on the pricing behaviour of Luxembourg firms” by P. Lünnemann and T. Y. Mathä, May 2006.

618 "The patterns and determinants of price setting in the Belgian industry" by D. Cornille and M. Dossche, May 2006.

619 "Cyclical inflation divergence and different labor market institutions in the EMU" by A. Campolmi and E. Faia, May 2006.

620 "Does fiscal policy matter for the trade account? A panel cointegration study" by K. Funke and C. Nickel, May 2006.

621 "Assessing predetermined expectations in the standard sticky-price model: a Bayesian approach" by P. Welz, May 2006.

622 "Short-term forecasts of euro area real GDP growth: an assessment of real-time performance based on vintage data" by M. Diron, May 2006.

623 "Human capital, the structure of production, and growth" by A. Ciccone and E. Papaioannou, May 2006.

624 "Foreign reserves management subject to a policy objective" by J. Coche, M. Koivu, K. Nyholm and V. Poikonen, May 2006.

625 "Sectoral explanations of employment in Europe: the role of services" by A. D'Agostino, R. Serafini and M. Ward-Warmedinger, May 2006.

626 "Financial integration, international portfolio choice and the European Monetary Union" by R. A. De Santis and B. Gérard, May 2006.

627 "Euro area banking sector integration: using hierarchical cluster analysis techniques" by C. Kok Sørensen, J. M. Puigvert Gutiérrez, May 2006.

628 "Long-run money demand in the new EU Member States with exchange rate effects" by C. Dreger, H.-E. Reimers and B. Roffia, May 2006.

629 "A market microstructure analysis of foreign exchange intervention” by P. Vitale, May 2006.

630 “Implications of monetary union for catching-up member states” by M. Sánchez, May 2006.

631 "Which news moves the euro area bond market?" by M. Andersson, L. J. Hansen and S. Sebestyén, May 2006.

632 "Does information help recovering structural shocks from past observations?" by D. Giannone and L. Reichlin, May 2006. 
633 "Nowcasting GDP and inflation: the real-time informational content of macroeconomic data releases" by D. Giannone, L. Reichlin and D. H. Small, May 2006.

634 "Expenditure reform in industrialised countries: a case study approach" by S. Hauptmeier, M. Heipertz and L. Schuknecht, May 2006.

635 "Identifying the role of labor markets for monetary policy in an estimated DSGE model" by K. Christoffel, K. Kuester and T. Linzert, June 2006.

636 "Exchange rate stabilization in developed and underdeveloped capital markets" by V. Chmelarova and G. Schnabl, June 2006.

637 "Transparency, expectations, and forecasts" by A. Bauer, R. Eisenbeis, D. Waggoner and T. Zha, June 2006.

638 "Detecting and predicting forecast breakdowns" by R. Giacomini and B. Rossi, June 2006.

639 "Optimal monetary policy with uncertainty about financial frictions" by R. Moessner, June 2006.

640 "Employment stickiness in small manufacturing firms" by P. Vermeulen, June 2006.

64I "A factor risk model with reference returns for the US dollar and Japanese yen bond markets" by C. Bernadell, J. Coche and K. Nyholm, June 2006.

642 "Financing constraints and firms' cash policy in the euro area" by R. Pál and A. Ferrando, June 2006.

643 "Inflation forecast-based-rules and indeterminacy: a puzzle and a resolution" by P. Levine, P. McAdam and J. Pearlman, June 2006.

644 "Adaptive learning, persistence, and optimal monetary policy" by V. Gaspar, F. Smets and D. Vestin, June 2006.

645 “Are internet prices sticky?” by P. Lünnemann and L. Wintr, June 2006.

646 "The Dutch block of the ESCB multi-country model" by E. Angelini, F. Boissay and M. Ciccarelli, June 2006.

647 "The economic effects of exogenous fiscal shocks in Spain: a SVAR approach" by F. de Castro Fernández and P. Hernández de Cos, June 2006.

648 "Firm-specific production factors in a DSGE model with Taylor price setting" by G. de Walque, F. Smets and R. Wouters, June 2006.

649 "Monetary and fiscal policy interactions in a New Keynesian model with capital accumulation and non-Ricardian consumers" by C. Leith and L. von Thadden, June 2006.

650 "A structural break in the effects of Japanese foreign exchange intervention on yen/dollar exchange rate volatility" by E. Hillebrand and G. Schnabl, June 2006. 
651 "On the determinants of external imbalances and net international portfolio flows: a global perspective” by R. A. De Santis and M. Lührmann, July 2006.

652 "Consumer price adjustment under the microscope: Germany in a period of low inflation" by J. Hoffmann and J.-R. Kurz-Kim, July 2006.

653 "Acquisition versus greenfield: the impact of the mode of foreign bank entry on information and bank lending rates" by S. Claeys and C. Hainz, July 2006.

654 "The German block of the ESCB multi-country model” by I. Vetlov and T. Warmedinger, July 2006.

655 "Fiscal and monetary policy in the enlarged European Union" by S. Pogorelec, July 2006.

656 "Public debt and long-term interest rates: the case of Germany, Italy and the USA" by P. Paesani, R. Strauch and M. Kremer, July 2006.

657 "The impact of ECB monetary policy decisions and communication on the yield curve" by C. Brand, D. Buncic and J. Turunen, July 2006.

658 "The response of firms" investment and financing to adverse cash flow shocks: the role of bank relationships” by C. Fuss and P. Vermeulen, July 2006.

659 “Monetary policy rules in the pre-EMU era: Is there a common rule?" by M. Eleftheriou, D. Gerdesmeier and B. Roffia, July 2006.

660 "The Italian block of the ESCB multi-country model" by E. Angelini, A. D'Agostino and P. McAdam, July 2006.

661 "Fiscal policy in a monetary economy with capital and finite lifetime" by B. Annicchiarico, N. Giammarioli and A. Piergallini, July 2006.

662 "Cross-border bank contagion in Europe” by R. Gropp, M. Lo Duca and J. Vesala, July 2006.

663 "Monetary conservatism and fiscal policy" by K. Adam and R. M. Billi, July 2006.

664 "Fiscal convergence before entering the EMU" by L. Onorante, July 2006. 
